\title{
Peripheral T-cell Lymphoma Prognostic Index Score 0
}

National Cancer Institute

\section{Source}

National Cancer Institute. Peripheral T-cell Lymphoma Prognostic Index Score O. NCI

Thesaurus. Code C161791.

A risk group associated with a total score of 0 on the Prognostic Index for Peripheral T-

cell Lymphoma indicating that an individual has a low risk. 